高分子綸文集 (Kobunshi Ronbunshu), Vol. 32, No. 3, pp. 162-167 (Mar., 1975)

\title{
過硫酸カリウムを開始剤とするメタクリル酸メチルとメタクリル酸 ジメチルアミノェチルの水媒体不均一共重合における特異現象*
}

\author{
松本 恒隆*1 $\cdot$ 大久保 政芳*1 $\cdot$ 尾上 勧*1
}

(受付 1974 年 10 月 3 日・靁查終了 1974 年 12 月 2 日)

\begin{abstract}
要 旨 過硫酸カリウム (KPS) を關始剂とするメタクリル酸メチル(MMA) とメタクリル酸ジメチ ルアミノェチル $(\mathrm{DM})$ との水媒体不均一共重合に㧍ける KPS と DM との相互作用について検討し, 次の諸結果を得た。1) 水相に存在する(仕込量の約 $20 \%$ ) DM は KPSの分解を著しく加速し, 重 合速度を增大させた。 ただし，KPS に対するDM のモル比が 30 (MMA との共重合モル比で表示 すれば，約 $8 \mathrm{~mol} \%)$ 以上では，KPS が重合途中で完全に分解し， dead end 重合となった。2) KPS の分解副生成物である $\mathrm{H}_{2} \mathrm{SO}_{4}$ の生成により, DM はプロトン化し, KPS の分解速度は低下 した。 3) DM は水中で簡単に加水分解し $\left(30^{\circ} \mathrm{C}, 24\right.$ 時間で約 $\left.80 \%\right)$, メタクリル酸とジメチルェタ ノールアミンの塩となり, KPS の分解加速能は消失した。この場合, 系の $\mathrm{pH}$ をアルカリ側に調節 すれば, ジメチルェタノールアミンが生成し, 分解加速能が発現した。
\end{abstract}

\section{1 緒言}

著者らは，先にアクリル酸エチルとカチオン性モノ、 一であるメタクリル酸ジメチルアミノェチル(DM) との 共重合体エマルジョン粒子によるへドロの凝集を試み, 通常の水溶性高分子凝集剤の場合とは異なり, 再分散性 のない凝集物が得られるといら與味ある結果を得た1. また，このエマルジョンを他のカルボキシル化高分子ェ マルジョンとブレンドし，イオン橋かけを生成させるこ とにより，強じんなフィルムを得ている2). ところで， 過硫酸カリウム (KPS) を開始剤として，このような共 重合体エマルショョンを作製する際，DMの仕込み量が多 くなると一定時間での最終の到達重合率が低く，KPS の追添加の必要のあることを認めた，ここて，DMは三 級アミノ基を有するモノマーであるが，同じ三級アミン のジメチルアニリンが過酸化ベンゾイルと酸化一還元反 応, いわゆるレドックス分解すること ${ }^{3)}$ ，また KPS と トリエタノールアミン系についても同様の現象が認めら れること4より，上記したェマルジョンの作製時に扸 る重合率が低いという現象は，モノマーである DM が KPS の分解になんらかの影響を及ぼすためではないか と予想された。実際，三級アミノ基を有するモ，マー (DM も含まれる) と過酸物開始剂との間で, 酸化一還 元反応が生起し，低温で重合可能と寸る特許が見られ るす．しかし，その詳細については明らかではない，そ

本研究を「サスペンジョン扩よびェマルジョンに関 する研究 第 19 報」とする

*1 神戸大学工学部工業化学教室 (®657 神戸市灘区六 甲台町 1)
こで, 本研究では KPS を開始剤とするメタクリル酸メ チル(MMA) と DM との水媒体不均一共重合における DM の役割について, 主に KPS の分解挙動の立場から 明らかにしょらとした。

\section{2 実験方法}

\section{1 試料}

DM および MMA は，常法で減圧蒸留して精製し た. KPS は市販特級品を 2 回再結晶法で精製した。 そ の他, ジメチルェタノールアミン (DA), ヨウ化カリウ ム $(\mathrm{KI})$, チ才硫酸ナトリウム $\left(\mathrm{Na}_{2} \mathrm{~S}_{2} \mathrm{O}_{3}\right), \mathrm{pH}$ 調節剂と してのホウ酸, 塩化カリウム, 水酸化ナトリウム, およ びリン酸などは，試薬特級品(和光純薬)をそのまま用い た. 水は比抵抗 $5 \times 10^{8} \Omega \cdot \mathrm{cm}$ のイオン交换水を，使用 直前に蒸留して使用した。

\section{2 釋衝液の作製}

pH 4 の緩衝液は Sörensen の pH 緩衝液, pH 6 10 のものは，それぞれ Clark の $\mathrm{pH}$ 緩衝液の作製法 に準じて作製しだ).

\section{3 過硫酸カリウムの分解率の測定}

KPS の分解は, $200 \mathrm{ml}$ の四つロフラスコを用い, 所 定濃度の DM 水溶液にイオン交換水, あるいは各種 $\mathrm{pH}$ の緩衝液を入れて $120 \mathrm{ml}$ とし，これに KPS $(1 \mathrm{~g} /$ $100 \mathrm{ml}$ ) 水溶液を $20 \mathrm{ml}$ 添加し, $30^{\circ} \mathrm{C}$, かき混ぜ速度 $350 \mathrm{rpm}$, 窒素気流中で行った。 分解率の測定は, Bartlett らの方法》に準じた。すなわち，上記反応系か ら, 試料 $10 \mathrm{~m} l$ を採取し, あらかじめ $50 \mathrm{ml}$ の三角フ ラスコ中に用意した水溶液 $\left(2 \mathrm{~N} \mathrm{H}_{2} \mathrm{SO}_{4} 20 \mathrm{ml}\right.$, 飽和 $\mathrm{KI}$ 水溶液 $5 \mathrm{~m} l$ ) に添加し, $\mathrm{CO}_{2}$ ふ心んい気中, 暗所で 30 分 
間放䐈後, スターラーでかくはんしながら， $0.01 \mathrm{~N} \mathrm{Na}_{2}$ $\mathrm{S}_{2} \mathrm{O}_{3}$ 水溶液で, 遊離したヨウ素を滴定し, 終点近くで デンプン指示薬を添加して無色になった点を終点とし た.

\section{4 イオン定数の決定}

$\mathrm{DM}$ のイオン定数 $\left(p K_{\mathrm{a}}\right)$ は, $0.1 \mathrm{~mol} / l$ 水溶液を 0.1 $N \mathrm{HCl}$ で電位差滴定し, その $50 \%$ 中和点の $\mathrm{pH}$ 值か ら求めた。皇の結果, $30^{\circ} \mathrm{C}$ での $\mathrm{DM}$ の $p K_{\mathrm{a}}$ は 7.85 であった．各 $\mathrm{pH}$ に批るイオン化率は, この $p K_{\mathrm{a}}$ を 用いて次式 ${ }^{8)}$ より算出した.

$$
\text { イオン化率 }(\%)=\frac{100}{1+\operatorname{antilog}\left(\mathrm{pH}-p K_{\mathrm{a}}\right)}
$$

\section{5 分解率の測定}

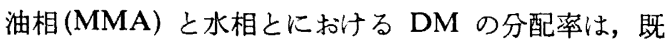
報量に従い, 重合系と同組成の MMA, 水, DM を $30^{\circ} \mathrm{C}$ で 15 分間振と5, 5 分間放置後, 水相を分離し, 電導度滴定により水相の DM 量を定量して求めた。

\subsection{DM の加水分解率の測定}

$\mathrm{DM}$ の加水分解率は, $0.0596 \mathrm{~mol} / l$ 水溶液を $30^{\circ} \mathrm{C}$ の恒温で放置し，加水分解により生成されるメタクリル 酸を $\mathrm{KOH}$ により電導度滴定して決定した。

\section{7 重合}

$18 \mathrm{~mm}$ 径の試験管に所定量の水 (または緩衝液), DM, MMA を入れ, 最後に KPS を添加した後, 窒素 置換を行って封管し，主に $30^{\circ} \mathrm{C}$ で振とらかき混ぜ重合 （振とう速度：約 180 回/分）を行った。

\section{3 結果および考察}

\section{1 過硫酸カリウムーメタクリル酸ジメチルアミノ エチルの相互作用}

\section{1. 1 MMA-DM の水媒体不均一系における共重} 合

Fig. 1 には, $60^{\circ} \mathrm{C}$, KPS を開始剤とした MMA一 DM の水媒体不均一共重合における，重合速度に及流 す DM の濃度の影響を示した，DM が存在しない系 (a 曲線)では, 仕込み後, 約 50 分で系が白濁し, 約 3.5 時間で重合はほぼ完結した。一方，DM が存在する 系では，KPS に対するDM のモル比 (以後 $M$ で表示) が 2 (b 曲線)，7 (c 曲線) と增加寸るにつれ，白濁開始 までの時間は短くなり，短時間で注ぼ $100 \%$ の重合率が 得られた。ところが， $M$ が 30 (d 曲線), 50 (e 曲線), 100 (f 曲線) と高い場合には，系の白濁拉よび重合は直 ちに起こるが，重合率は100に達せず，最終到達重合率 がそれぞれ約 60,50，および 30\% と低下した。なお， ここで $M$ が 30,50 という值は，モノ、ーが完全に重 合したとして，共重合体中の DM 含有量が，それぞれ $8.0,12.7 \mathrm{~mol} \%$ といら值に対応し，これはカチオン性 エマルジョンを作製するのに, 我々が通常用いる組成で

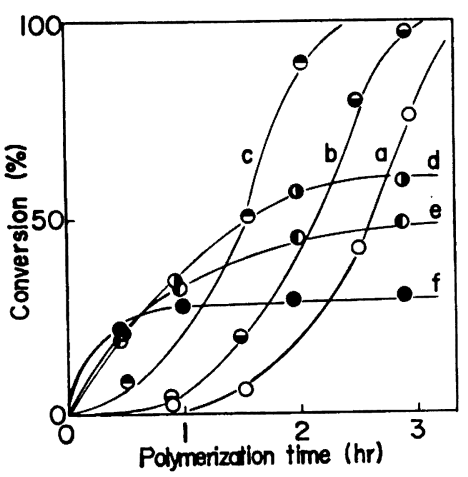

Fig. 1. Effect of the concentration of dimethylaminoethyl methacrylate on the copolymerization with methyl methacrylate in deionized water at $60^{\circ} \mathrm{C}$.

MMA, $1.7 \mathrm{~mol} / l$; KPS, $4.93 \times 10^{-3} \mathrm{~mol} / l$. $\mathrm{DM} / \mathrm{KPS}$ (mol ratio): $\bigcirc, 0 ; \ominus, 2 ; \Theta, 7$; (), 30;, $50 ; \bullet, 100$.

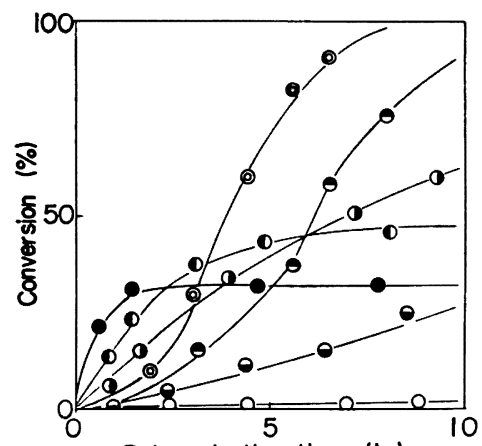

Polymerizotion time ( $h r)$

Fig. 2. Effect of the concentration of dimethylaminoethyl methacrylate on the copolymerization with methyl methacrylate in deionized water at $30^{\circ} \mathrm{C}$.

MMA, $1.7 \mathrm{~mol} / l ; \mathrm{KPS}, 4.93 \times 10^{-8} \mathrm{~mol} / l$. $\mathrm{DM} / \mathrm{KPS}$ (mol ratio): 0,$0 ; \Theta, 2 ; \Theta, 7$; ๑ , $10 ; \bigcirc, 30 ; \bigcirc, 50 ; \bullet, 100$.

ある。このよらに，モノマーである DM が，重合速度 に著しい影響を与えたが，この上うな現象は，酸化一還 元系を形成しない水溶性アゾ系開始剤である $2,2^{\prime}$-アゾ ビス(2-アミジノプロパソ) 塩酸塩を開始剤とした場合に は認められなかった(図省略)。これらのことょり，三級 アミノ基を有する DM が過酸化物である KPS と酸 化一還元反応を起こし，KPS の分解を加速させる効果 を有しているのではないかと推測される。なお， $M=30$ 以上の系に批る最終到達重合率の低下もその効果が激 し過ぎるため，KPS が途中で完全に分解し，重合開始 
にあずかる KPS が消失したと考えれば合理的に説明で きる，そこで，次に通常レドックス采開始剂を用いた重 合で選定される $30^{\circ} \mathrm{C}$ といら低温で，Fig. 1 と同一の 実験を行った。

Fig. 2 にその結果を示した。四から明らかなように， この温度で, DM が存在しない系 $(M=0)$ では, 10 時 間経過しても重合はほとんど起こらなかった。一方, $\mathrm{DM}$ が存在する共重合系では, $M=2,7,10$ と增加する につれ，重合が促進され， $M=10$ では 6.5 時間で約 $90 \%$ の重合率に達した， $M=30$ 以上では，Fig. 1 の $60^{\circ} \mathrm{C}$ の場合と同様の挙動を示した。 このことは，上述 した, DM モノマーが KPS の分解を促進するとい5見 解をさらに強く支持するものである. そこで, 次に実際 に, DM 存在下での KPS の分解速度を測定した。

\subsubsection{KPS の分解に及ほす DM の効果}

Fig. 3 には, $30^{\circ} \mathrm{C}$ 泧ける DM 存在下での KPS の分解曲線を示した. KPS 単独 $(M=0)$ では, 10 時間 経過してもほとんど分解しないのに対し， $M$ が 1,2,4, 7 …と增加するにつれ, その効果は著しく, 特に $M=$ 10 以上では, 約 20 分内で分解は終っている. ところ が, Fig. 2 で示した $M=10$ の系では，重合率は約 20 分で 10\%，8 時間でほぼ $100 \%$ となり，20 分以上で は，KPS が全く残存していないのに, 重合が進行した ことになる.なお，Fig. 2 の $M=30,50$,および 100 に ついても, 重合率は $100 \%$ に達していないが(この点に ついては後述する), やはり重合が進行している，かか る矛盾点については，DM が水に溶解するだけでなく， MMA にも完溶であることから，重合系では MMA 相 にDM が分配され，KPS の存在する水相には仕込及量 よりも少ない量しか存在しないためではないかと考えら

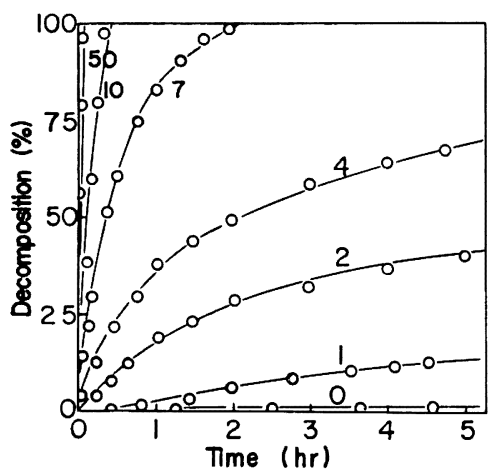

Fig. 3. Effect of the concentration of dimethylaminoethyl methacrylate on the decomposition of potassium persulfate in deionized water at $30^{\circ} \mathrm{C}$.

KPS, $4.93 \times 10^{-8} \mathrm{~mol} / l$, Numbers on curves indicate the mol ratio $(M)$ of $\mathrm{DM} / \mathrm{KPS}$.
れる，そこで，この点を明確にするため， MMA 相と 水相とにおける DM の分配率を検討した.

\subsubsection{DM の MMA 相およひ水相への分配事}

Table 1 にその結果を示した. ここで, No. 1,2, 抒 よび 3 は，それぞれ Fig. 2 における $M=10,50$ および 100 の系に対応する．表から明らかなよらに，それぞれ の場合について仕込み DM 量の約 $20 \%$ しか水相に存 在しないことが分かる.したがって，実際の重合系で, 例壳ば $M=10$ の場合, 水相での $M$ 值は 2.3 であり, KPS の分解は, Fig. 3 の $M=2$ にほぼ対応する。 ま た，重合が進行するにつれて，DMは生成粒子中へ吸着 され, 水相の DM 量はさらに減少すると考えられる. それゆえ， $M=10$ でも，実際の重合系での KPS の分 解はそれほど激しくなく, Fig. 2 のような重合曲線(○) 曲線)が得られたのであろら。しかし， $M$ が 50 および 100 の場合，水相には DM が，それぞれ約 $M=10$ お よび 20 だけは存在するわけで, Fig. 3 の結果から考 え, Fig. 2 に打忛る重合が dead end 状態になったこ とも理解できる.

ところでここれまで行ってきた重合および DM 存在 下での KPS の分解率の測定は, DM 水溶液を作成後, 直ちに行ってきたが，その水溶液を約 1 週間室温放置 後, 同様の実験を行ったところ, Fig. 1 3 で示した DM に上る重合加速効果拈よび KPS の分解加速効果は 全く認められないか，または非常に弱くなり，その水容 液の $\mathrm{pH}$ は作成直後に比べて約 2 汪ど低下していた。 このことは，DM によるKPS の分解加速効果に系の $\mathrm{pH}$ および DM の加水分解性が関与していることを示 唆している. そこで, 以下かかる諸因子について検討を 加光た。

Table 1. Distribution of dimethylaminoethyl methacrylate between methyl methacrylate and water at $30^{\circ} \mathrm{C}$.

MMA $20 \mathrm{~m} l$

\begin{tabular}{cccc}
\hline \hline No. & $\begin{array}{c}\text { Water } \\
(\mathrm{m} l)\end{array}$ & $\begin{array}{c}\text { DM } \\
(\mathrm{m} l)\end{array}$ & $\begin{array}{c}\text { Distribution of DM } \\
\text { in water }(\%)\end{array}$ \\
\hline 1 & 90.1 & 0.9 & 23.3 \\
2 & 85.5 & 4.5 & 22.3 \\
3 & 80.9 & 9.1 & 21.8 \\
\hline
\end{tabular}

\subsection{DM による KPS の分解加速効果に及ほす諸因} 子

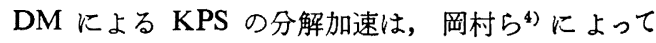
明らかにされた KPSートリメタノールアミン系におけ る知見に基づけば, 次の (1), (2) で示される酸化一還元 過程に従って起こると考えられる。 


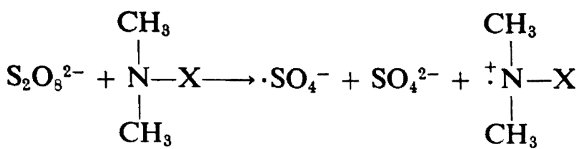<smiles></smiles>

この (1), (2) 式の分解過程で実際:反応が生起している ならば, 当然，(3) 式で示される 2 次反応式が適用され るはずである。そこで，本 KPS-DM 系の (3) 式への 適用性について検討した。

$$
\frac{1}{2 a-b} \ln \frac{b(a-x)}{a(b-2 x)}=k_{2} t
$$

ここで， $x$ は時間 $t$ に扑ける KPS の分解モ儿数， $a$, $b$ はそれぞれ KPS, DM の初濃度， $k_{2}$ は分解速度定数 である.

Fig. 4 には, $M \doteqdot 2$ の場合の KPS の分解率 (a 曲線) を(3) 式に適用した結果を示した (c 曲線). 図から明ら かなよ5に， c 曲線は約 15\% とい5低分解率の付近 (図 中 A 点）より，直線から低くずれ始めた。 ここで, DM がモノマーであることを考虑すれば，KPS と DM の酸化一還元反応上り生成したラジカル $\left(\cdot \mathrm{SO}_{4}^{-}\right)$が, (4) 式で示される DM との付加反応に消費されること も考えられる.

$$
\begin{aligned}
& \cdot \mathrm{SO}_{4}^{-}+\mathrm{CH}_{2}=\underset{X}{\mathrm{CH}} \longrightarrow-\mathrm{O}_{4} \mathrm{~S}-\mathrm{CH}_{2}-\underset{\mid}{\mathrm{CH}} \cdot \\
& \mathrm{X}=\mathrm{COOC}_{2} \mathrm{H}_{4} \mathrm{~N}\left\langle\mathrm{CH}_{\mathrm{CH}_{3}}^{\mathrm{CH}_{3}}\right.
\end{aligned}
$$

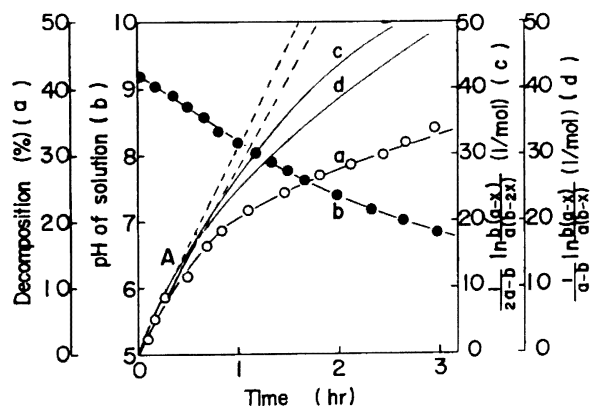

Fig. 4. The decomposition curve of potassium persulfate and its second-order reaction plot in the presence of dimethylaminoethyl methacrylate in deionized water at $30^{\circ} \mathrm{C}$.

KPS, $4.93 \times 10^{-3} \mathrm{~mol} / l ; \mathrm{DM}, 9.53 \times 10^{-3}$ $\mathrm{mol} / \mathrm{l}$.
事実, NMR 测定により，(4) 式の生起が確認された。 いま，(2) 式が起こらず，すべて (4) 式が起こるものと すれば, 次の (5) 式で解析を行ら必要がある.

$$
\frac{1}{a-b} \ln \frac{b(a-x)}{a(b-x)}=k_{2} t
$$

その結果を Fig. 4 に併記した (d 曲線)が，その場合に も，(3) 式に基つうく c 曲線と同様, 直線ではなかった。 実際には，(3) と（5）式が共存するような系で反応が進 行しているが，いずれにしても，2 次反応式を満足する とは考えられない。

Fig. 4 には, さらに KPS の分解に伴ら系の pH 变 化を併記した (b 曲線)。図から明らかな上らに, KPS の 分解に伴って系の $\mathrm{pH}$ は 9.2 から 6.7 付近までほぼ直 線的に低下している。 この $\mathrm{pH}$ の低下は KPS の分解に 伴う $\mathrm{H}_{2} \mathrm{SO}_{4}$ の生成 ${ }^{10)}$ によるものと思われる机，てのた め DM の三級了ミノ基はプロトン化される。 ここで， プロトン化したアミノ基が KPS に対して還元能，つま り分解加速能をもたないと考光れば，(3) および（5) 式 に执いて，b值(DM の初濃度) がレドックス反応とは 無関係に漸次低下寸ることから, a 曲線の結果が 2 次 反応式に合わないことも理解できる。 そこで，次にこの 点を明確にするために $\mathrm{pH}$ を一定に保った采，つまり 各種 $\mathrm{pH}$ の緩衝液中での KPS の分解および MMA一 DM 共重合速度に及汸す DM の影響について検討し た.

\section{3. $2.1 \mathrm{pH}$ の影響}

Fig. 5 にその結果を示した.な拉，系の pH の差異 によるKPS の分解率の比較は, 時間一分解率曲線にお ける初期勾配から求めた分解初速度 $\left(R d_{0}\right)$ で行ない表示 した，図から明らかなように，pH が低下寸るにつれて $R d_{0}$ 証下寸る傾向 (a 曲線)を示して拉り, $\mathrm{pH} か 3.6$ 緩衝液中では，もはや KPS はほとんど分解しなかっ た。これに対応して重合速度も $\mathrm{pH}$ が低くなるにつれ て低下しており(b-3，b-6 曲線)， $\mathrm{pH}$ が 4.6 では，10 時 間後でも重合せず，DM が存在しない系と同様の結果 を示した。 このことから，三級了ミノ基のプロトン化状 態にあるものはKPS の分解加速能を全くもたないこと が明らかとなった。

さて，このよらな結果より，前述したように Fig. 4 で示した 2 次反応プロットの非直線性の原因が，(3),

(5) 式中の $b$ 值の連続的变化にもかかわらず, 仕込及時 の $\mathrm{DM}$ 濃度を $b$ 值 (一定) として用いたためであるこ とが示唆された，そこで， pH 低下沪伴う DM のプロ トン化による $b$ 值の変化を, 逐次補正した場合の 2 次 反応プロットの直線性を検討した。なお，ここで，その 補正は 2.4 で求めた $\mathrm{DM} の p K_{\mathrm{a}}$ 值を用いて行った。

Fig. 6 にその結果を示した. 図から明らかなよらに, Fig. 4 で示した KPS の分解率曲線の 2 次反応プロッ 


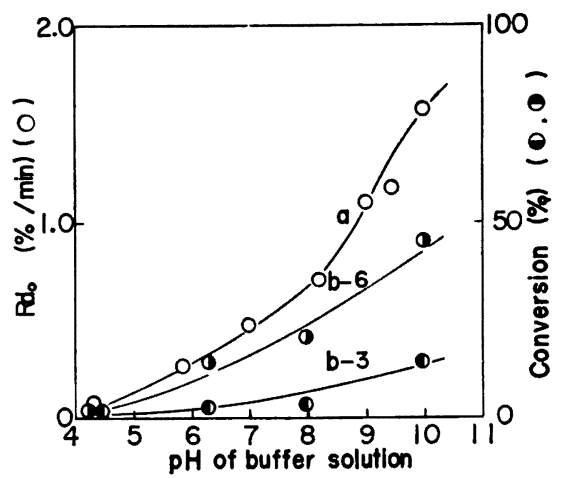

Fig. 5. Effect of $\mathrm{pH}$ on the conversion of methyl methacrylate and initial rate of decomposition of potassium persulfate in the presence of dimethylaminoethylmethacrylate at $30^{\circ} \mathrm{C}$.

$\mathrm{KPS}, 4.93 \times 10^{-8} \mathrm{~mol} / l ; \mathrm{DM}, 2.0 \times 10^{-2}$ $\mathrm{mol} / l$; MMA, $1.7 \mathrm{~mol} / l$.

Polymerization time (hr): (I, 3; O, 6.

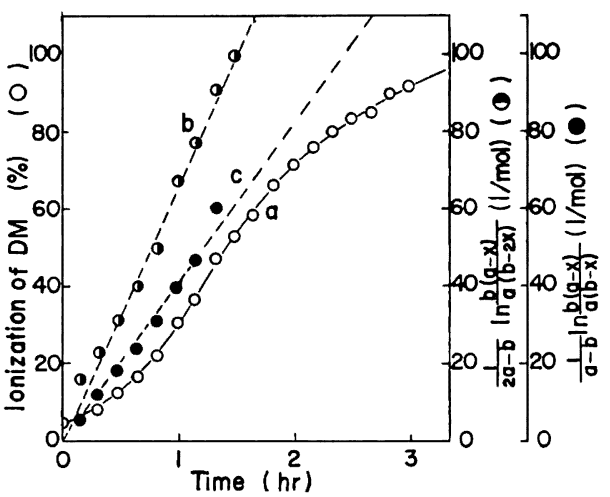

Fig. 6. The corrected second-order reaction plot for the ionization of dimethylaminoethylmethacrylate.

$\mathrm{KPS}, 4.93 \times 10^{-3} \mathrm{~mol} / l ; \mathrm{DM}, 9.53 \times 10^{-3}$ $\mathrm{mol} / l$; Temp., $30^{\circ} \mathrm{C}$.

ト((3), (5) 式によるプロット) は，各時刻における系の $\mathrm{pH}$ 值から DM のイオン化率を求め (c 曲率), $b$ 值を補 正することにより，かなり良い直線性が得られた $(\mathrm{a}, \mathrm{b}$ 曲線).このことは, 上記した理由の妥当であること、い いか觉れば, かかるプロトン化する還元剂と, 分解して 系の $\mathrm{pH}$ を低下させるよらな酸化剂(開始剤) との間の レドックス反応においては, 系の $\mathrm{pH}$ 值の变化に十分 注意することの重要性が示された。なお，大津ら ${ }^{11}$ は過 酸化ペンゾイルとジメチルアニリンのレドックス系にお いて生成される $\mathrm{C}_{8} \mathrm{H}_{5}-\stackrel{+}{\mathrm{N}}$ がジメチルアニリンの作用に
より脱プロトン化して $\mathrm{C}_{6} \mathrm{H}_{5} \mathrm{~N}\left(\mathrm{CH}_{3}\right) \mathrm{CH}_{2}$ ・になり，し かもこれが重合開始能を有すると報告している。このよ らな知見に基つけげ，本系においても(1)，(2) 式より生 成される $\mathrm{X}-\mathrm{+}+\mathrm{N}\left(\mathrm{CH}_{3}\right)_{2}$ が同様の反応を起こし, 上記速 度論的解析および重合に若干の影響を与えると思われる が，一応本報告の論点には大した影響を与えないと考兄 られたので無視した。

\section{3. $2.2 \mathrm{DM}$ の加水分解}

前述したように, DM は水溶液中で加水分解を起こ すことが推測された，DM の加水分解物がメタクリル 酸とジメチルェタノールフミンの塩になることから， 3.2.1 の知見に従之ば, 当然, 加水分解物は KPS の分 解加速能をもたない，また，DM を共重合して，反応性 をポリマーに付与する立場から考兄ても，このような加 水分解の生起が好ましくないことは，いうまでもない， そこで，まず DM の加水分解性を検討し，その結果を Fig. 7 に示した.

Fig. 7 から明らかなように, 放置時間の增加とともに， DM の加水分解率は增大し， 24 時間で初期の約 80\% が加水分解した (a 曲線)。また，この加水分解率曲線を 一次反応プロットした結果を併記したが(b 曲線), 直線 性を示していることより，この加水分解の反応が一次反 応で起こり，濃度依存性のないことが分かった。このよ 5に, DM は水溶液中で比較的簡単に加水分解するこ とが明らかとなった。

ところで，このよらな加水分解が自己触媒的に生起し ていることを考虑すれば，pH の高い緩衝液中の方が当 然それは大きくなると考えられる。.と寸れば，Fig. 5 の 緩衝液中での結果に拉いて，pH の高い系の方がより KPS の分解加速能が大きいという現象に対して, 単に 加水分解されていない三級アミノ基の還元能だけでは説 明がつかない，そこで，この点に関して完全分解した

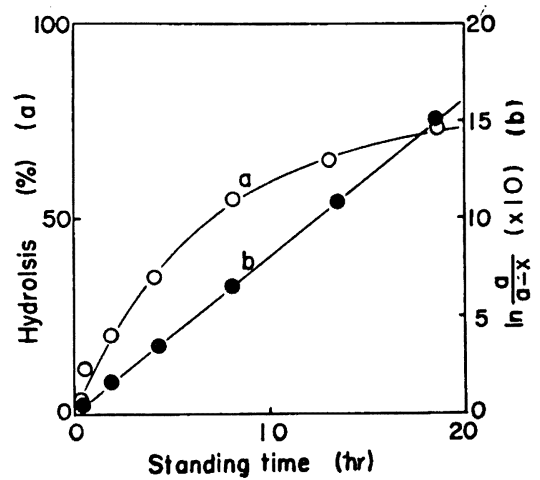

Fig. 7. Relationship between the standing time and hydrolysis of dimethylaminoethylmethacrylate in deionized water at $30^{\circ} \mathrm{C}$.

$\mathrm{DM}, 0.0596 \mathrm{~mol} / l$. 


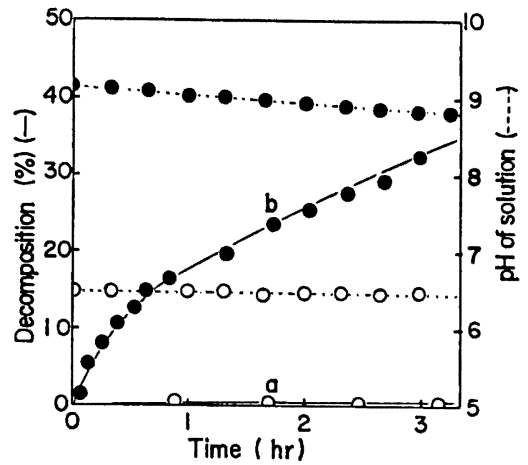

Fig. 8. Effect of $\mathrm{pH}$ on the decomposition of potassium persulfate in the presence of hydrolyzed dimethylaminoethyl methacrylate at $30^{\circ} \mathrm{C}$.

KPS $4.93 \times 10^{-3} \mathrm{~mol} / l$, hydrolyzed DM $9.3 \times 10^{-8} \mathrm{~mol} / l$.

$\bigcirc$, deionized water $(\mathrm{pH}=6.4) ; \bullet$, buffer solution ( $\mathrm{pH}=9.2)$.

$\mathrm{DM}$ を用いて緩衝液 $(\mathrm{pH}=9.2)$ 中での重合および KPS の分解挙動を検討した。

Fig. 7 にその結果を示した。四から明らかなように イオン交換水中では (a 曲線)，ほとんど KPS の分解が 認められないのに対し，pH 9.2 の緩衝夜中では (b 曲 線), 未加水分解 DM の場合とほぼ同程度の分解加速が 認められた。この理由については次のように考えた。前 述したように，DM はイオン交換水中で，加水分解し て(A)のよらな塩の型で存在しそのため還元能がない.<smiles>C=C(C)C(=O)OCCN(C)CC=C(C)C(=O)O[N+](C)(C)CCO</smiles>

(A)
しかし，この系に緩衝液を添加して $\mathrm{pH}$ をフルカリ 側に調節することにより，A は B に移行し, 第三アミ ンである DA が生成し，これが DM と同様 KPS の 分解を加速する. このような見解は，実際に，DA が KPS の分解を加速することから支持された.

以上の結果から，KPS を開始剂とする MMA とDM との水媒体不均一共重合に扎いて, DM モノマーが水 中で徐々に加水分解するため, 目的とする組成比の共重 合物が得にくいといら問題点を内蔵しているが，pH お よび DM 仕込み量の調節をらまく行えば, DM-KPS レドックス開始剤系の形成により，低温でも短時間で $100 \%$ 重合可能であることが明らかとなった。

付 記 本研究は第 20 回高分子研究発表会(1974 年, 神戸)で発表したものである。

\section{文献}

1) 松本恒隆，大久保政芳，陶 正史：日本接着協 会誌, 8, 303 (1972).

2) 松本恒隆，大久保政芳：日本化学会第 27 秋季 年会誌 $(1972$, 名古屋).

3) Y. Imoto, S. Choe: J. Polym. Sci., 15, 485 (1955).

4) 林 晃一郎, 岡村誠三：高分子化学, 11, 59 (1954).

5) 一キスト合成(株)：日特, 昭和 47-10051.

6) 森 五彦: “汇紙ゾーン電気泳動の実際”, 南江 堂 (1965) p. 192.

7) P. D. Bartlett, R. Altschul: J. Amer. Chem. Soc., 67, 812 (1945).

8) A. Albert, E. P. Serjeant (松浦貞郎訳): “仡 オン定数”，丸善 (1963), p. 9.

9) 松本恒隆, 鵳田 勝: 高分子化学, 22, 172 (1965).

10) 例えば，J. N. Friend: A. Texbook of Inorganic Chemistry, VII, p. 183.

11) T. Sato, T. Otsu: Makromol. Chem., 125, 1 (1969).<smiles>CC(=C[GaH])C(=O)O[Na]</smiles>

(B)

$\left(\mathrm{M}=\mathrm{K}^{+}, \mathrm{Na}^{+}\right)$ 